\title{
1 Negligible microbial heterotrophic \\ 2 quantitative contribution onto trace metals 3 remobilization during marine sediment 4 resuspension - insights from a 5 Mediterranean urbanized bay
}

6

Nicolas Layglon $^{1, \mathrm{a}^{*}}$, Benjamin Misson ${ }^{1}$, Nicolas Gallois ${ }^{1, \mathrm{~b}}$, Sébastien D'Onofrio ${ }^{1}$, Véronique Lenoble ${ }^{1}$, Stéphane Mounier ${ }^{1}$, Dario Omanović ${ }^{2}$, Cédric Garnier ${ }^{1}$

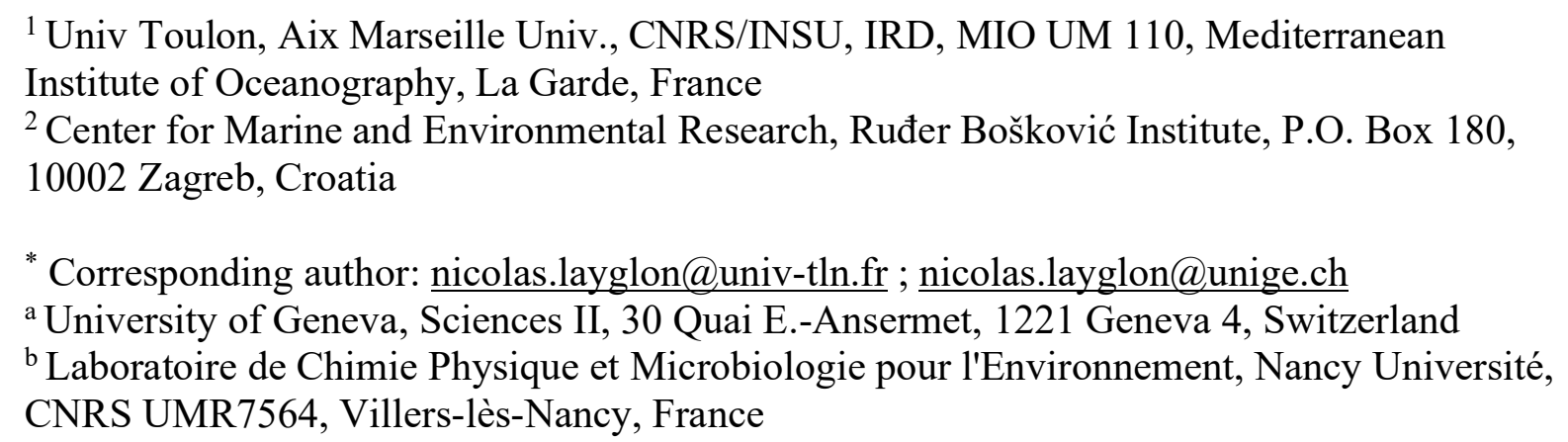


Abstract

Marine sediments are a sink for trace metals but also a potential source during sediment resuspension events. Understanding the factor that regulates this uptake or release of contaminant is of prime importance. While the impact of abiotic processes has been widely studied, the quantitative influence of microbial activities on metal cycling during sediment resuspension events is still largely unknown. This study was designed to quantify such microbial contributions on the cycling of a suite of metals ( $\mathrm{Al}, \mathrm{As}, \mathrm{Ba}, \mathrm{Co}, \mathrm{Cr}, \mathrm{Cs}, \mathrm{Cu}, \mathrm{Fe}, \mathrm{Li}, \mathrm{Mn}, \mathrm{Mo}, \mathrm{Ni}, \mathrm{Pb}$, $\mathrm{Rb}, \mathrm{Sb}, \mathrm{Sr}, \mathrm{Ti}, \mathrm{Tl}, \mathrm{U}, \mathrm{V}$ and $\mathrm{Zn}$ ) and evaluate the specific contributions of heterotrophic micro-organisms originating from either the seawater or the sediment. For that purpose, the sediment and seawater were selectively sterilized using either autoclave (sediment) or filtration under $0.2 \mu \mathrm{m}$ (seawater) prior to be mixed for 5 days in darkness. Dissolved concentration in trace elements were measured over time, along with physical-chemical parameters. The $\mathrm{pH}$ in the different conditions decreased all along the experiments while the redox potential decreased during up to 4 days before increasing back to its initial value. Three groups of trace metals were identified: metals whose dissolved concentrations (1) increased (Al, Ba, Co, Cs, $\mathrm{Cu}, \mathrm{Mn}, \mathrm{Mo}, \mathrm{Ni}, \mathrm{Pb}, \mathrm{Sb}, \mathrm{Tl}, \mathrm{U}$ and $\mathrm{Zn}$ ) as a consequence of the transfer from sediment, (2) decreased ( $\mathrm{Cr}$, Fe and $\mathrm{Ti}$ ) as a consequence of transfer onto sediment, and (3) remained unchanged over time ( $\mathrm{As}, \mathrm{Li}, \mathrm{Rb}, \mathrm{Sr}$ and $\mathrm{V}$ ). The sterilization of either sediment and/or seawater did not have a statistically significant impact onto the dynamics of the physical-chemical parameters, nor onto the metals' behavior (except Mn). Our results demonstrate (i) that marine sediment autoclaving prior to mixing with seawater did not disrupt the behavior of metals in the seawater / sediment mixing over the 5 days of experiments and (ii) that the microbial activity had a negligible influence on the variation of physical-chemical parameters or metals' transfers over the mixing time.

\section{Keywords}

Marine sediment resuspension; metals mobility; microbial contribution; short-term 


\section{Introduction}

Understanding the processes affecting the mobility of contaminants at the solid-liquid interface is key to assess the importance of sediment resuspension events in marine system as a potential source of pollution (Caille et al., 2003; Comber et al., 1996; Shipley et al., 2011; Zouch et al., 2018). When mixing occur, physical-chemical conditions such as redox potential, $\mathrm{pH}$ or solid/liquid ratio may change drastically compare to those in the sediment (Caille et al., 2003; Dang et al., 2020; Shipley et al., 2011). Microbial responses also vary significantly within hours to months, as demonstrated by studies focusing on the phytoplankton dynamics (Coclet et al., 2018; Lafabrie et al., 2013) or on the structure and functional properties of the prokaryotic community (Galand et al., 2016; Störmer et al., 2013; Won et al., 2017; Zouch et al., 2018). Planktonic active microbes can react very quickly to the large input of organic matter and nutrients in oxic water (Coclet et al., 2018; Lafabrie et al., 2013; Schäfer et al., 2001). On the other hand, the microbial flora of anoxic sediment could be largely inhibited by resuspension in oxic waters, with only dormant aerobic bacteria being able to develop after reactivation. It is clear that different successive microbial communities will occur after a sediment resuspension event. However, while the impact of abiotic drivers on the release and mobility of trace metals has been extensively studied, the impact of microbial communities is largely unknown.

Geochemical changes from sterilization techniques is a major scientific problem, as recently revealed for a widely used inorganic poison, sodium azide (Layglon et al., 2020). Physical techniques (autoclaving and gamma irradiation) are known to increase the surface area of clays and significantly alter the organic matter structure (Berns et al., 2008; Kelsey et al., 2010; McNamara et al., 2003), although the impact of such changes on metal transfers during seawater-sediment mixing has not been documented yet.

The present study aimed to both evaluate the influence of sediment autoclaving and quantify the contribution of benthic and planktonic heterotrophic microbes on metal transfers (between sediment and seawater, one way or another) during the resuspension of marine sediment in seawater. For that purpose, four different resuspension experiments were conducted: (1) a control experiment with unprocessed seawater and sediment, (2) both compartments were sterilized prior to mixing (in order to evaluate the whole microbial contribution) and (3 and 4) selective sterilizations of either water or sediment were performed. Dissolved oxygen concentrations, $\mathrm{pH}$, Eh and dissolved metals concentrations were measured after several contact time up to five days, since in most of the cases, sediment resuspension does not extend beyond this duration in the natural environment.

\subsection{Sampling and samples pre-treatment}


For the purpose of this work, the sediment was sampled in an enclosed area of Toulon Bay (in the naval harbor, coordinates 43.11454 N, $5.885418 \mathrm{E}$ ), ensuring the sampling of heavily-contaminated fine sediment (Cossa et al., 2017; Misson et al., 2016; Wafo et al., 2016). The sediment core was sampled with an Uwitec interface corer equipped with PVC® tubes of $90 \mathrm{~mm}$ in diameter. The first $30 \mathrm{~cm}$ of the sediment core was homogenized under inert atmosphere, in order to prepare a composite sediment.

In addition, seawater was sampled in a less contaminated part of the bay $(43.08528 \mathrm{~N}, 6.02002 \mathrm{E})$.

Twenty-five litres of surface $(-0.5 \mathrm{~m})$ seawater were sampled using a $4.2 \mathrm{~L}$ horizontal van Dorn type water sampler (Wildco, model Beta) and stored at ambient temperature into a clean 25 L LDPE bottle (Nalgene) previously rinsed three times with water from the site. The experiments were conducted within $4 \mathrm{~h}$. / v HCl, pro analysis, Fisher Scientific) and fully rinsed with Milli-Q water (18.2 M $\Omega$, Millipore) in the laboratory to avoid contamination.

\subsection{Laboratory resuspension experiments}

This work was carried out in order to study to what extent microbial activity can impact geochemical transfers during sediment resuspension events. Four different experiments were performed: 1- sediment and seawater remained unprocessed to assess the geochemical remobilization in natural samples (later referred as "control condition"); 2- both sediment and seawater were sterilized to assess the abiotic contribution in the geochemical transfers (later referred as all sterilized); 3- the sediment was sterilized while the seawater remained unprocessed (later referred as sterilized sediment) to assess the microbial contribution from benthic microorganisms by comparison to control condition and 4- the seawater was sterilized while the sediment remained unprocessed (later referred as "sterilized seawater") to assess the planktonic microbial contribution by comparison to control condition.

103 Seawater sterilization was ensured by two successive filtrations using syringe filters $(0.2 \mu \mathrm{m}$ cellulose acetate

104 filters) (Black et al., 2012; Laturnus et al., 2000; Pouliquen et al., 2007) while sediment sterilization was performed

105 by autoclaving sediment twice for 20 minutes, observing a cooling period until the sediment were at room 106 temperature after each operation (Otte et al., 2018; Tuominen, 1994). Precautions were taken to minimize both 107 microbial and chemical contaminations during the experiments by using sterile material and by sampling and 108 manipulating under a clean laminar flow hood. 
Assuming that the development of residual microbes after sterilization would take place after a certain lag time, the experiments were carried out only on a short time scale to limit the risks induced by the development of

111 residual microorganisms. Cabrol et al. (2017) demonstrated in similar experiments but without sterilization that 112 the density of free-living prokaryotes was still increasing after four days. Thus, the experiments lasted 5 days to 113 focus on the normal development period of microorganisms in the mixing.

114 For each experiment, the sediment was mixed with the seawater (with a ratio corresponding to $2.5 \mathrm{~g}$ of wet 115 sediment for $1 \mathrm{~L}$ of seawater, i.e. $\sim 1.2 \mathrm{~g}$ of dry sediment for $1 \mathrm{~L}$ of seawater) into $1 \mathrm{~L}$ FEP bottles. All experiments 116 were performed in triplicates. All the bottles were submitted to continuous overhead shaking ( $15 \mathrm{rpm}$; Heidolph 117 Reax 20) in an opaque box to prevent sunlight influence. Water-sediment mixture was sub-sampled after 30 min, 1181 hour, 1, 2, 3, 4 and 5 days of contact time.

119 Each sub-sample was filtered through a $0.2 \mu \mathrm{m}$ cellulose acetate syringe filter (Sartorius) and stored into 120 HDPE bottles, acidified to $0.2 \% \mathrm{HNO}_{3}$ s.p. (Merck) and kept at ambient temperature until the analysis of dissolved 121 trace metal concentrations.

122 The same mixtures were reproduced in parallel, in 1 L HDPE bottles in order to monitor $\mathrm{pH}$ and the redox 123 potential (Eh) through the experiment, avoiding any contamination in FEP bottles. For that, we used PHC101 and 124 MTC101 multi-parameter probes (Hach).

125 Daily aeration was ensured to avoid oxygen-depletion-related variations in the experiment by opening 126 HDPE and FEP bottles few minutes.

\section{Chemical analyses}

128 The concentrations of dissolved Al, As, Ba, Co, Cr, Cs, Cu, Fe, Li, Mn, Mo, Ni, Pb, Rb, Sb, Sr, Ti, Tl, U, $129 \mathrm{~V}$ and Zn were measured by High Resolution Inductively Coupled Plasma Mass Spectrometer (Element 2, HR 130 ICP-MS, Thermo), with a 10-fold dilution for seawater samples to reduce salt-matrix effect. All samples were 131 spiked with an Internal Standard (Indium). A certified reference material (CASS-5, Nearshore seawater reference 132 material for metals, National Research Council Canada) was used as a quality control of HR ICP-MS 133 measurements. Two separate CASS-5 control samples were measured after every 10-15 samples, giving at the end 134 6-10 of control measurements (depending on the sequence length). Matrix matching calibration (in 10-fold diluted 135 CASS-5 sample) was used for concentration quantification. Determined concentrations of metals in CASS-5 136 sample were within $10 \%$ of the certified values.

$137 \quad$ 2.3. Statistical analyses 

way repeated measure ANOVA and pairwise comparisons. The p-value was adjusted with Bonferroni method.

140 Correlations between dissolved metals concentrations were assessed by Spearman's correlation tests. All statistical analyses and heatmap visualizations were performed using RStudio (R Core Team, 2015) and packages agricolae, ggpubr, gridExtra, Hmisc, reshape2, rstatix and stats.

\section{Results and Discussions}

\subsection{Physical-chemical parameters short-term variations are not linked to microbial activities}

In the control experiment, $\mathrm{pH}$ significantly decreased over time $\left(\mathrm{p}\right.$-value $\left.=2.17 \mathrm{e}^{-10}\right)$ from a starting value of 7.99 to a final value of 7.76 (Figure 1. A). Eh decreased over time up to 4 days ( $\mathrm{p}$-value $=1.18 \mathrm{e}^{-6}$ ) from a starting value of $180 \mathrm{mV}$ to a final value of $154 \mathrm{mV}$ (Figure 1. B). This Eh decrease could be due to reduced species input with sediment addition. At the end of the experiment (after 5 days of mixing) the Eh value returned to the initial value (p-value $>0.05)$ (Figure 1. B), probably due to regular aeration of the mixture. Such results were already reported in biotic sediment / seawater mixing experiments (Cabrol et al., 2017; Dang et al., 2014; Pía Di Nanno et 152 al., 2007; Zouch et al., 2018). The pH decrease over the time was presumed to be due to the development / respiration of microorganisms having suddenly access to a large pool of bioavailable organic matter (Dang et al.,

154 2020). Although a microbial activity could have led to dissolved oxygen depletion (Moriarty, 1997), in our experiments $\mathrm{O}_{2}$ didn't significantly vary (p-value $>0.05$ ) and remained within the range 8.58 to $8.84 \mathrm{mg} . \mathrm{L}^{-1}$

156 (Figure 1. C), showing that the daily opening of the bottles during our experiment was sufficient to prevent microbial inhibition by oxygen depletion.

158 The results obtained in experiments 2 and 3 where sediment was autoclaved showed no statistical difference 159 (p-value $>0.05$ ) compared to the control condition. Such observation tends to demonstrate that sediment 160 autoclaving did not disrupt the processes controlling $\mathrm{pH}$, Eh and $\mathrm{O}_{2}$ variations in this study.

Furthermore, the results obtained with the selective sterilizations showed that sterilization of sediment and / 162 or seawater did not affect the variation of $\mathrm{pH}$, Eh and $\mathrm{O}_{2}$ too ( $\mathrm{p}$-value $>0.05$ ). This conclusion implies that the 163 variation of $\mathrm{pH}$ and $\mathrm{Eh}$ is mainly due to abiotic processes, which is in agreement with a previous work conducted 164 with a different sterilization method (autoclaving and inorganic poison) and sediment originating from the same 165 bay (Layglon et al., 2020). Thereafter, the pH decrease, commonly recorded during sediment resuspension 166 experiments, could be linked to the increasing concentration of dissolved acid substances through abiotic processes 
rather than to microbial mineralization of organic substrates. Further confrontation of this result to the resuspension of a wide panel of sediment quality is however required to determine the abiotic processes leading to $\mathrm{pH}$ decrease.

\subsection{Transfer of metals are mostly due to abiotic processes during sediment resuspension}

Beyond Toulon Bay, sediment resuspension can occur in any shallow marine environment following strong wind episodes. In harbors, sediment resuspension might also be induced by boat mooring and maneuver or dredging. During sediment resuspension in the water column, metals may either remain undisturbed by the mixing, or undergo transfers consisting in a removal by or a desorption from particles (Calmano et al., 1993; Dang et al., 2020, 2015; Layglon et al., 2020). Such processes are element dependent and follow different kinetics (Dang et al., 2020; Monnin et al., 2018).

In the control condition, three groups of metals showing three behaviors over time were identified through correlation analysis (Supplementary Information). The first group gathered metals whose dissolved concentration increased over time: $\mathrm{Al}, \mathrm{Ba}, \mathrm{Co}, \mathrm{Cs}, \mathrm{Cu}, \mathrm{Mn}, \mathrm{Mo}, \mathrm{Ni}, \mathrm{Pb}, \mathrm{Sb}, \mathrm{Tl}, \mathrm{U}$ and $\mathrm{Zn}$ (a representative example is presented in Figure 2. A). Such progressive desorption was previously attributed to sulfide oxidation and organic matter mineralization (Dang et al., 2020; Layglon et al., 2020; Monnin et al., 2018; Saulnier and Mucci, 1999). The oxidation of sulfide phase was attributed to the extended aeration of the sediment, therefore such oxidation was mostly attributed to abiotic processes (Caille et al., 2003). The organic matter oxidation / mineralization was mostly attributed to microbial activity which is enhanced when organic matter is released from anoxic to oxic media (Aller, 1998; Bastviken et al., 2004; Hulthe et al., 1998).

The second group gathered metals whose dissolved concentration decreased over time: $\mathrm{Cr}, \mathrm{Fe}$ and $\mathrm{Ti}$ (a representative example is presented in Figure 2. B). During resuspension, such decrease (adsorption) could mostly be due to the addition of carrier phases with sediment addition as well as Fe oxy-hydroxides precipitation (Dang et al., 2020; Layglon et al., 2020). Over time, Fe and Mn generally spontaneously and abiotically precipitate under oxy-hydroxides forms in presence of oxygen (Atkinson et al., 2007; Dang et al., 2020; Hirst and Aston, 1983;

191 Monnin et al., 2018; Vdović et al., 2006; Vidal-Durà et al., 2018). However, in our experiment, dissolved Mn did not decrease over time, its dynamic differs from Fe.

193 The third group gathered metals whose dissolved concentration did not appear to change significantly over

194 time: As, Li, Rb, Sr and V (a representative example is presented in Figure 2. C, metals with the same behavior 195 over time are presented in $\mathbf{S I})$. 
The results obtained with the selective sterilizations showed that seawater sterilization did not affect the behavior of metals in our experiments (p-value $>0.05$ ) (Figure 2 et 3). In the experiments where the sediment was sterilized,

198 the behavior of the metals tested (except Mn) showed no statistical difference when compared to control condition whatever the sampling time (p-value $>0.05$ ). This is in contradiction with the observations of Chifflet et al., (2019) who showed that autoclaving sediment / seawater mix strongly impacted the dissolved concentration of several metals. However, since autoclaving is based on an increase in temperature and pressure, and as the solubility constant depends on temperature and pressure as well as sediment / seawater ratio, an increase in solubilization of the metals at high temperatures may have introduce some equilibrium changes. Thus, to study the microbial contribution on the geochemical transfer of metals, sediment should be autoclaved separately prior to mixing in seawater to reduce temperature and pressure impact. Although sediment alterations are inevitable by autoclaving, this study tends to demonstrate that separate sterilization avoids altering the transfers. Although autoclaving sediment is a disparaged method, it seems to be much more appropriate, when studying metals transfers during sediment resuspension experiments, than the use of azide as previously demonstrated (Layglon et al., 2020). Hence, results suggest that the bacterial activity on the geochemical transfer of the metals is negligible during short term mixing ( 5 days) when compared to the influence of abiotic processes, a behavior that should now be better deciphered for modelling-based sediment management in contaminated areas.

Mn was the only impacted element by sediment sterilization. Indeed, dissolved Mn concentration were higher in the mixing after three days in experiments where the sediment was sterilized (p-value $\left.=4.19 \mathrm{e}^{-14}\right)($ Figure 3).

214 Such differentiation between the control experiment and the experiment where the sediment was sterilized could 215 have different origins. Higher dissolved Mn concentration after autoclaving was already observed by Wolf et al., 216 (1989) and it was ascribed to the enhanced Mn oxides dissolution due to the autoclave treatment. Reduction of Mn 217 oxides related to organic matter degradation by bacteria as described by Magen et al., (2011) is excluded in our 218 case because such mechanism was associated to anaerobic conditions, whereas our samples were fully oxygenated. 219 Furthermore, selective extraction revealed that Mn in our samples was mainly in the form of sulfide and not oxide 220 (Layglon et al., in prep). In previous studies, Mn was found to be mainly oxidized through biologically-mediated pathways (Learman et al., 2011). Therefore, in this work the inhibition of the microbial community responsible of 222 such oxidation would lead to an increase of dissolved $\mathrm{Mn}$ as observed in the experiments where the sediment was 223 sterilized. Thus, it could be hypothesized that the increase in dissolved Mn in the experiments where the sediment 224 was sterilized was not due to Mn oxides dissolution after autoclave treatment, but to the removal of benthic microorganisms preventing $\mathrm{Mn}$ oxidation. If the oxidation of $\mathrm{Mn}$ (II) was mainly biologically mediated by 
plankton, the dissolved Mn concentration in our experiments should be higher in the sterilized seawater condition in comparison to the control condition. However, only the sterilization of seawater did not affect the dissolved concentration of $\mathrm{Mn}$ when compared to the control condition ( $\mathrm{p}$-value $>0.05$ ). Thus, plankton did not seem to regulate Mn behavior during sediment resuspension.

\section{Conclusion}

232 The present study clearly reports an absence of disturbance of both the physical-chemical parameters and geochemical transfers in sediment / seawater mixing after sediment autoclaving. Results suggest that the decrease in $\mathrm{pH}$, hitherto proposed as resulting from the degradation of organic matter by microbial activity generating acid substances, could be largely due to abiotic processes. Abiotic processes also appeared to be the main drivers of the remobilization of potentially toxic trace metals. Furthermore, this work tends to demonstrate that the microbial influence on metals' behavior remains negligible, metals transfers between sediment and water mainly relying on abiotic processes at least during the first 5 days. Similar studies carried out with sediments of various quality and various microbial communities should be performed to assess the generality of these results.

Ethics approval and consent to participate

Not applicable

\section{Consent for publication}

Not applicable

\section{Authors' contributions}

N.L., B.M, V.L and S.M designed the study. N.L, S.D'O. and N.G prepared the experiments and collected the samples. N.L., S.D'O. and D.O. performed the analysis. N.L., B.M, V.L and S.M interpreted the raw and collected data. N.L., B.M, V.L and S.M wrote the original draft. All the authors read, revised and approved the manuscript.

\section{Funding}

254 This study was financially supported by the project SE.D.RI.PORT. (SEdimenti, Dragagi e RIschi PORTuali,

255 Interreg Marittimo IT/FR 2017-2020, co-funded by European Regional Development Fund). This work was realized also as a part of the project "New methodological approach in biogeochemical studies of metal speciation in coastal aquatic ecosystems" (MEBTRACE) (IP-2014-09-7530), financially supported by the Croatian Science

258 Foundation. N. Layglon PhD was partly funded by Sud region and supported by LASEM Toulon.

\section{Availability of data and materials}




\section{Conflict of Interest Statement}

The authors declare that they have no known competing financial interests or personal relationships that could have appeared to influence the work reported in this paper.

$\square$ The authors declare the following financial interests/personal relationships which may be considered as potential competing interests:

\section{Acknowledgements}

271 The authors thank Louis Longo and Alexis Canino for their help during sampling. The authors greatly appreciate

272 the work of Dr Pascal Salaun (Liverpool University, Earth, Ocean and Ecological Sciences) for the English edition 273 of the paper.

274 This work is dedicated to Cédric Garnier. We will always remember him as an outstanding scientist, a committed colleague and friend who left us too soon. 
Aller, R.C., 1998. Mobile deltaic and continental shelf muds as suboxic, fluidized bed reactors. Mar. Chem. 61, 143-155. https://doi.org/10.1016/S0304-4203(98)00024-3 Atkinson, C.A., Jolley, D.F., Simpson, S.L., 2007. Effect of overlying water pH, dissolved oxygen, salinity and sediment disturbances on metal release and sequestration from metal contaminated marine sediments. Chemosphere 69, 1428-1437. https://doi.org/10.1016/j.chemosphere.2007.04.068

Bastviken, D., Persson, L., Odham, G., Tranvik, L., 2004. Degradation of dissolved organic matter in oxic and anoxic lake water. Limnol. Oceanogr. 49, 109-116. https://doi.org/10.4319/lo.2004.49.1.0109 Berns, A.E., Philipp, H., Narres, H.-D., Burauel, P., Vereecken, H., Tappe, W., 2008. Effect of gammasterilization and autoclaving on soil organic matter structure as studied by solid state NMR, UV and fluorescence spectroscopy. Eur. J. Soil Sci. 59, 540-550. https://doi.org/10.1111/j.1365-2389.2008.01016.x Black, F.J., Poulin, B.A., Flegal, A.R., 2012. Factors controlling the abiotic photo-degradation of monomethylmercury in surface waters. Geochim. Cosmochim. Acta 84, 492-507. https://doi.org/10.1016/j.gca.2012.01.019 Cabrol, L., Quéméneur, M., Misson, B., 2017. Inhibitory effects of sodium azide on microbial growth in experimental resuspension of marine sediment. J. Microbiol. Methods 133, 62-65. https://doi.org/10.1016/j.mimet.2016.12.021

Caille, N., Tiffreau, C., Leyval, C., Morel, J.L., 2003. Solubility of metals in an anoxic sediment during prolonged aeration. Sci. Total Environ. 301, 239-250. https://doi.org/10.1016/S0048-9697(02)00289-9 Calmano, W., Hong, J., Förstner, U., 1993. Binding and Mobilization of Heavy Metals in Contaminated Sediments Affected by $\mathrm{pH}$ and Redox Potential. Water Sci. Technol. 28, 223-235. https://doi.org/10.2166/wst.1993.0622 Chifflet, S., Quéméneur, M., Barani, A., Angeletti, B., Didry, M., Grégori, G., Pradel, N., 2019. Impact of sterilization methods on dissolved trace metals concentrations in complex natural samples: Optimization of UV irradiation. MethodsX 6, 1133-1146. https://doi.org/10.1016/j.mex.2019.04.020

Coclet, C., Garnier, C., Delpy, F., Jamet, D., Durrieu, G., Le Poupon, C., Mayer, M., Misson, B., 2018. Trace metal contamination as a toxic and structuring factor impacting ultraphytoplankton communities in a multicontaminated Mediterranean coastal area. Prog. Oceanogr. 163, 196-213. https://doi.org/10.1016/j.pocean.2017.06.006 Comber, S.D.W., Gardner, M.J., Gunn, A.M., Whalley, C., 1996. Kinetics of trace metal sorption to estuarine suspended particulate matter. Chemosphere 33, 1027-1040. https://doi.org/10.1016/0045-6535(96)00244-5 Cossa, D., Durrieu de Madron, X., Schäfer, J., Guédron, S., Marusczak, N., Castelle, S., Naudin, J.-J., 2017. Sources and exchanges of mercury in the waters of the Northwestern Mediterranean margin. Prog. Oceanogr. 163, 172-183. https://doi.org/10.1016/j.pocean.2017.05.002

Dang, D.H., Layglon, N., Ferretto, N., Omanović, D., Mullot, J.-U., Lenoble, V., Mounier, S., Garnier, C., 2020. Kinetic processes of copper and lead remobilization during sediment resuspension of marine polluted sediments. Sci. Total Environ. 698. https://doi.org/10.1016/j.scitotenv.2019.134120

Dang, D.H., Schäfer, J., Brach-Papa, C., Lenoble, V., Durrieu, G., Dutruch, L., Chiffoleau, J.-F., Gonzalez, J.-L., Blanc, G., Mullot, J.-U., Mounier, S., Garnier, C., 2015. Evidencing the Impact of Coastal Contaminated Sediments on Mussels Through Pb Stable Isotopes Composition. Environ. Sci. Technol. 49, 11438-11448. https://doi.org/10.1021/acs.est.5b01893

Dang, D.H., Tessier, E., Lenoble, V., Durrieu, G., Omanović, D., Mullot, J.-U., Pfeifer, H.-R., Mounier, S., Garnier, C., 2014. Key parameters controlling arsenic dynamics in coastal sediments: An analytical and modeling approach. Mar. Chem. 161, 34-46. https://doi.org/10.1016/j.marchem.2014.02.005

Galand, P.E., Lucas, S., Fagervold, S.K., Peru, E., Pruski, A.M., Vétion, G., Dupuy, C., Guizien, K., 2016.

Disturbance Increases Microbial Community Diversity and Production in Marine Sediments. Front. Microbiol. 7. https://doi.org/10.3389/fmicb.2016.01950

Hirst, J.M., Aston, S.R., 1983. Behaviour of copper, zinc, iron and manganese during experimental resuspension and reoxidation of polluted anoxic sediments. Estuar. Coast. Shelf Sci. 16, 549-558.

https://doi.org/10.1016/0272-7714(83)90085-9

Hulthe, G., Hulth, S., Hall, P.O.J., 1998. Effect of oxygen on degradation rate of refractory and labile organic matter in continental margin sediments. Geochim. Cosmochim. Acta 62, 1319-1328.

https://doi.org/10.1016/S0016-7037(98)00044-1

Junta, J.L., Hochella, M.F., 1994. Manganese (II) oxidation at mineral surfaces: A microscopic and spectroscopic study. Geochim. Cosmochim. Acta 58, 4985-4999. https://doi.org/10.1016/0016-7037(94)90226-7 Kelsey, J.W., Slizovskiy, I.B., Peters, R.D., Melnick, A.M., 2010. Sterilization affects soil organic matter chemistry and bioaccumulation of spiked p,p'-DDE and anthracene by earthworms. Environ. Pollut. 158, 22512257. https://doi.org/10.1016/j.envpol.2010.02.011 
Lafabrie, C., Garrido, M., Leboulanger, C., Cecchi, P., Grégori, G., Pasqualini, V., Pringault, O., 2013. Impact of contaminated-sediment resuspension on phytoplankton in the Biguglia lagoon (Corsica, Mediterranean Sea). Estuar. Coast. Shelf Sci. 130, 70-80. https://doi.org/10.1016/j.ecss.2013.06.025 Laturnus, F., Giese, B., Wiencke, C., Adams, F.C., 2000. Low-molecular-weight organoiodine and organobromine compounds released by polar macroalgae - The influence of abiotic factors. Fresenius J. Anal. Chem. 368, 297-302. https://doi.org/10.1007/s002160000491 studies in sediments been misinterpreted? Sci. Total Environ. 707, 135949.

https://doi.org/10.1016/j.scitotenv.2019.135949

Learman, D.R., Wankel, S.D., Webb, S.M., Martinez, N., Madden, A.S., Hansel, C.M., 2011. Coupled bioticabiotic $\mathrm{Mn}$ (II) oxidation pathway mediates the formation and structural evolution of biogenic Mn oxides. Geochim. Cosmochim. Acta 75, 6048-6063. https://doi.org/10.1016/j.gca.2011.07.026

Magen, C., Mucci, A., Sundby, B., 2011. Reduction Rates of Sedimentary Mn and Fe Oxides: An Incubation Experiment with Arctic Ocean Sediments. Aquat. Geochem. 17, 629-643. https://doi.org/10.1007/s10498-0109117-9

McNamara, N.P., Black, H.I.J., Beresford, N.A., Parekh, N.R., 2003. Effects of acute gamma irradiation on chemical, physical and biological properties of soils. Appl. Soil Ecol. 24, 117-132.

https://doi.org/10.1016/S0929-1393(03)00073-8

Misson, B., Garnier, C., Lauga, B., Dang, D.H., Ghiglione, J.-F., Mullot, J.-U., Duran, R., Pringault, O., 2016. Chemical multi-contamination drives benthic prokaryotic diversity in the anthropized Toulon Bay. Sci. Total Environ. 556, 319-329. https://doi.org/10.1016/j.scitotenv.2016.02.038

Monnin, L., Ciffroy, P., Garnier, J.-M., Ambrosi, J.-P., Radakovitch, O., 2018. Remobilization of trace metals during laboratory resuspension of contaminated sediments from a dam reservoir. J. Soils Sediments 18, 25962613. https://doi.org/10.1007/s11368-018-1931-5

Moriarty, D.J.W., 1997. The role of microorganisms in aquaculture ponds. Aquaculture 151, 333-349. https://doi.org/10.1016/S0044-8486(96)01487-1

361 Otte, J.M., Blackwell, N., Soos, V., Rughöft, S., Maisch, M., Kappler, A., Kleindienst, S., Schmidt, C., 2018.

Sterilization impacts on marine sediment---Are we able to inactivate microorganisms in environmental samples? FEMS Microbiol. Ecol. 94. https://doi.org/10.1093/femsec/fiy 189

Pía Di Nanno, M., Curutchet, G., Ratto, S., 2007. Anaerobic sediment potential acidification and metal release risk assessment by chemical characterization and batch resuspension experiments. J. Soils Sediments 7, 187194. https://doi.org/10.1065/jss2007.04.220

Pouliquen, H., Delépée, R., Larhantec-Verdier, M., Morvan, M.-L., Le Bris, H., 2007. Comparative hydrolysis and photolysis of four antibacterial agents (oxytetracycline oxolinic acid, flumequine and florfenicol) in deionised water, freshwater and seawater under abiotic conditions. Aquaculture 262, $23-28$.

https://doi.org/10.1016/j.aquaculture.2006.10.014

Saulnier, I., Mucci, A., 1999. Trace metal remobilization following the resuspension of estuarine sedments: Saguenay Fjord, Canada. Appl. Geochem. 15, 191-210.

Schäfer, H., Bernard, L., Courties, C., Lebaron, P., Servais, P., Pukall, R., Stackebrandt, E., Troussellier, M., Guindulain, T., Vives-Rego, J., Muyzer, G., 2001. Microbial community dynamics in Mediterranean nutrientenriched seawater mesocosms: changes in the genetic diversity of bacterial populations. FEMS Microbiol. Ecol. 34, 243-253. https://doi.org/10.1111/j.1574-6941.2001.tb00775.x

Shipley, H.J., Gao, Y., Kan, A.T., Tomson, M.B., 2011. Mobilization of Trace Metals and Inorganic Compounds during Resuspension of Anoxic Sediments from Trepangier Bayou, Louisiana. J. Environ. Qual. 40, 484. https://doi.org/10.2134/jeq2009.0124

Störmer, R., Wichels, A., Gerdts, G., 2013. Geo-Chip analysis reveals reduced functional diversity of the bacterial community at a dumping site for dredged Elbe sediment. Mar. Pollut. Bull. 77, 113-122. https://doi.org/10.1016/j.marpolbul.2013.10.022

Tuominen, L., 1994. Comparison of Methods for Inhibiting Bacterial Activity in Sediment. Appl. Environ. Microbiol. 60, 3454-3457.

Vdović, N., Billon, G., Gabelle, C., Potdevin, J.-L., 2006. Remobilization of metals from slag and polluted sediments (Case Study: The canal of the Deûle River, northern France). Environ. Pollut. 141, 359-369. https://doi.org/10.1016/j.envpol.2005.08.034 Vidal-Durà, A., Burke, I.T., Stewart, D.I., Mortimer, R.J.G., 2018. Reoxidation of estuarine sediments during simulated resuspension events Effects on nutrient and trace metal mobilisation. Estuar. Coast. Shelf Sci. 207, 4055. https://doi.org/10.1016/j.ecss.2018.03.024

Wafo, E., Abou, L., Nicolay, A., Boissery, P., Perez, T., Ngono Abondo, R., Garnier, C., Chacha, M., Portugal, H., 2016. A chronicle of the changes undergone by a maritime territory, the Bay of Toulon (Var Coast, France), and their consequences on PCB contamination. SpringerPlus 5. https://doi.org/10.1186/s40064-016-2715-2 Wolf, D.C., Dao, T.H., Scott, H.D., Lavy, T.L., 1989. Influence of Sterilization Methods on Selected Soil 
Microbiological, Physical, and Chemical Properties. J. Environ. Qual. 18, 39.

Won, N.-I., Kim, K.-H., Kang, J., Park, S., Lee, H., 2017. Exploring the Impacts of Anthropogenic Disturbance on Seawater and Sediment Microbial Communities in Korean Coastal Waters Using Metagenomics Analysis. Int. J. Environ. Res. Public. Health 14, 130. https://doi.org/10.3390/ijerph14020130 Zouch, H., Cabrol, L., Chifflet, S., Tedetti, M., Karray, F., Zaghden, H., Sayadi, S., Quéméneur, M., 2018. Effect of Acidic Industrial Effluent Release on Microbial Diversity and Trace Metal Dynamics During Resuspension of Coastal Sediment. Front. Microbiol. 9. https://doi.org/10.3389/fmicb.2018.03103
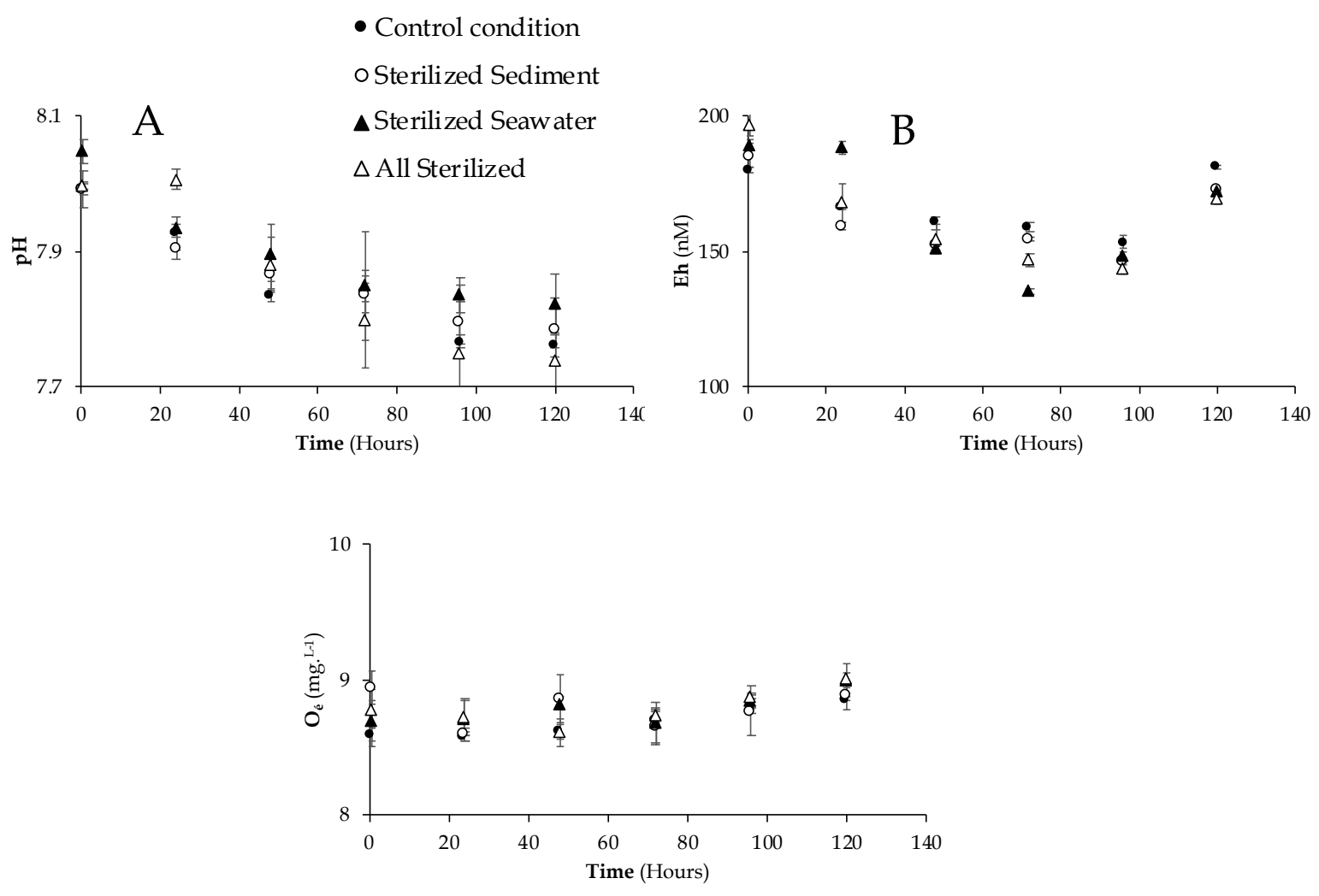

407 Figure 1. Variation of $\mathrm{pH}(\mathrm{A})$, Eh (B) and $\mathrm{O}_{2}(\mathrm{C})$ during the resuspension experiment in the control condition.

408 Only control condition is represented since there was no significant difference between conditions over time and since points were largely overlapping. 

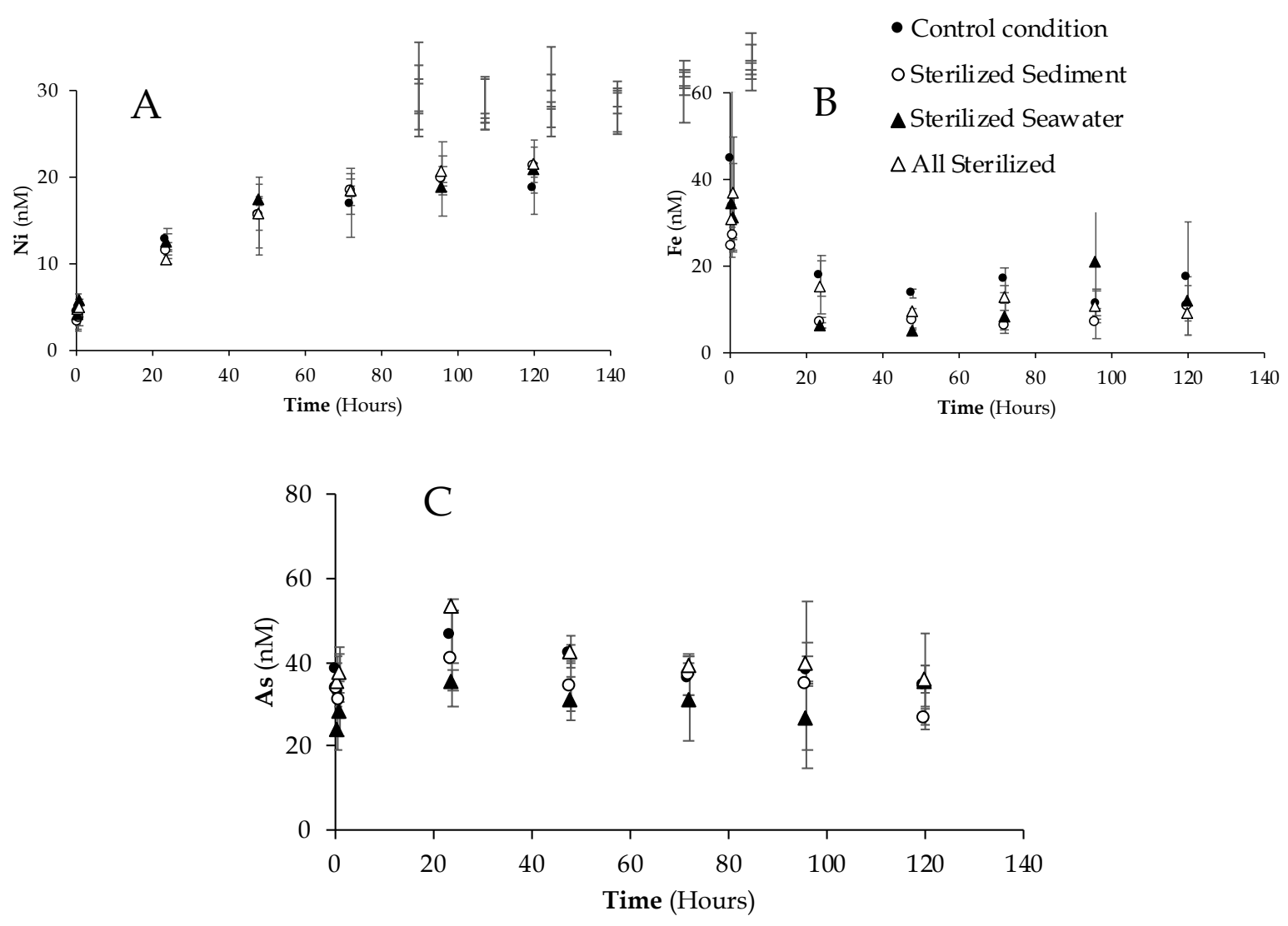

412 Figure 2. Metals whose dissolved concentrations increased (A), decreased (B), and remained unchanged (C) in 413 the control condition after $30 \mathrm{~min}, 1 \mathrm{~h}, 1,2,3,4$ and 5 days of resuspension experiment. The metals displayed here 414 belong to larger groups discriminated statistically in SI. Only control condition is represented since there was no 415 significant difference between conditions over time and since points were largely overlapping.

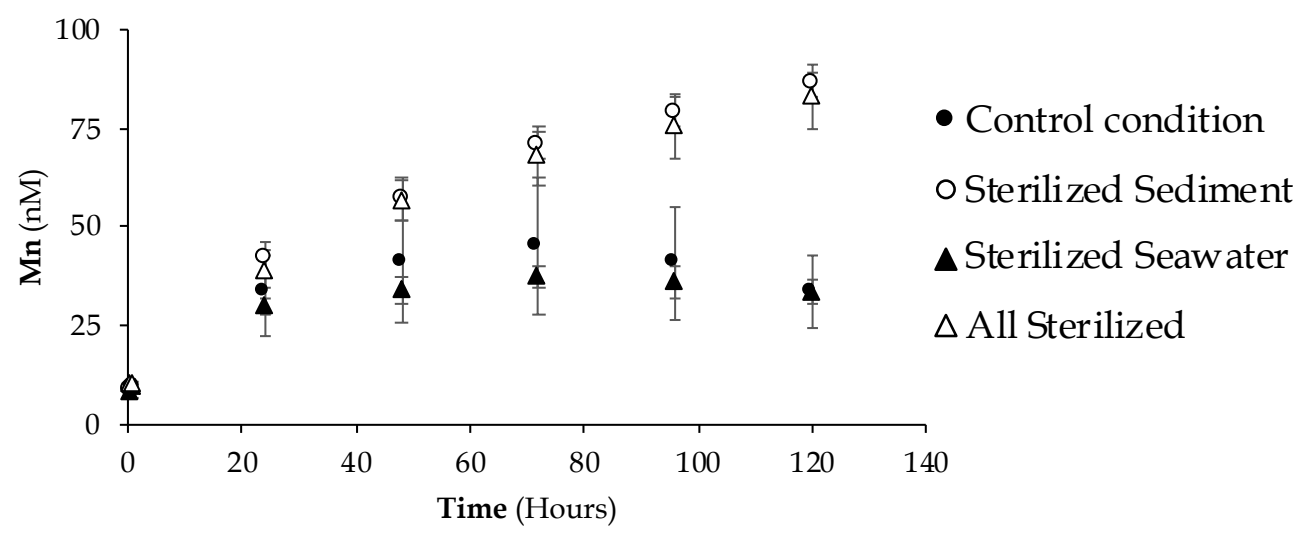

418 Figure 3. Variation of dissolved Mn during the resuspension experiments throughout different sterilization 419 conditions after $30 \mathrm{~min}, 1 \mathrm{~h}, 1,2,3,4$ and 5 days of mixing. 


\section{Supplementary Information}

421 In order to have a quick overview of metals having the same behavior over the 5 days

422 of experiment in the control condition (i.e. sediment and water continuous mixing at a ratio of

4231 g.L ${ }^{-1}$ eq. DW), Spearman's correlation tests were performed from 21 measurements 424 corresponding to 7 triplicated sampling times. The heatmap correlation clearly showed three 425 main groups, one with the metals ranging from $\mathrm{Mo}$ to $\mathrm{Pb}$, a second with the metals ranging 426 from $\mathrm{Rb}$ to $\mathrm{V}$ and a third one with those ranging from $\mathrm{Ti}$ to Fe. The first cluster corresponded 427 to metals whose concentration was increasing over time during the seawater-sediment mixing 428 experiment. The second main cluster represented the metals whose dissolved concentration 429 didn't change while the third one represented the metals whose dissolved concentration 430 decreased over time. 


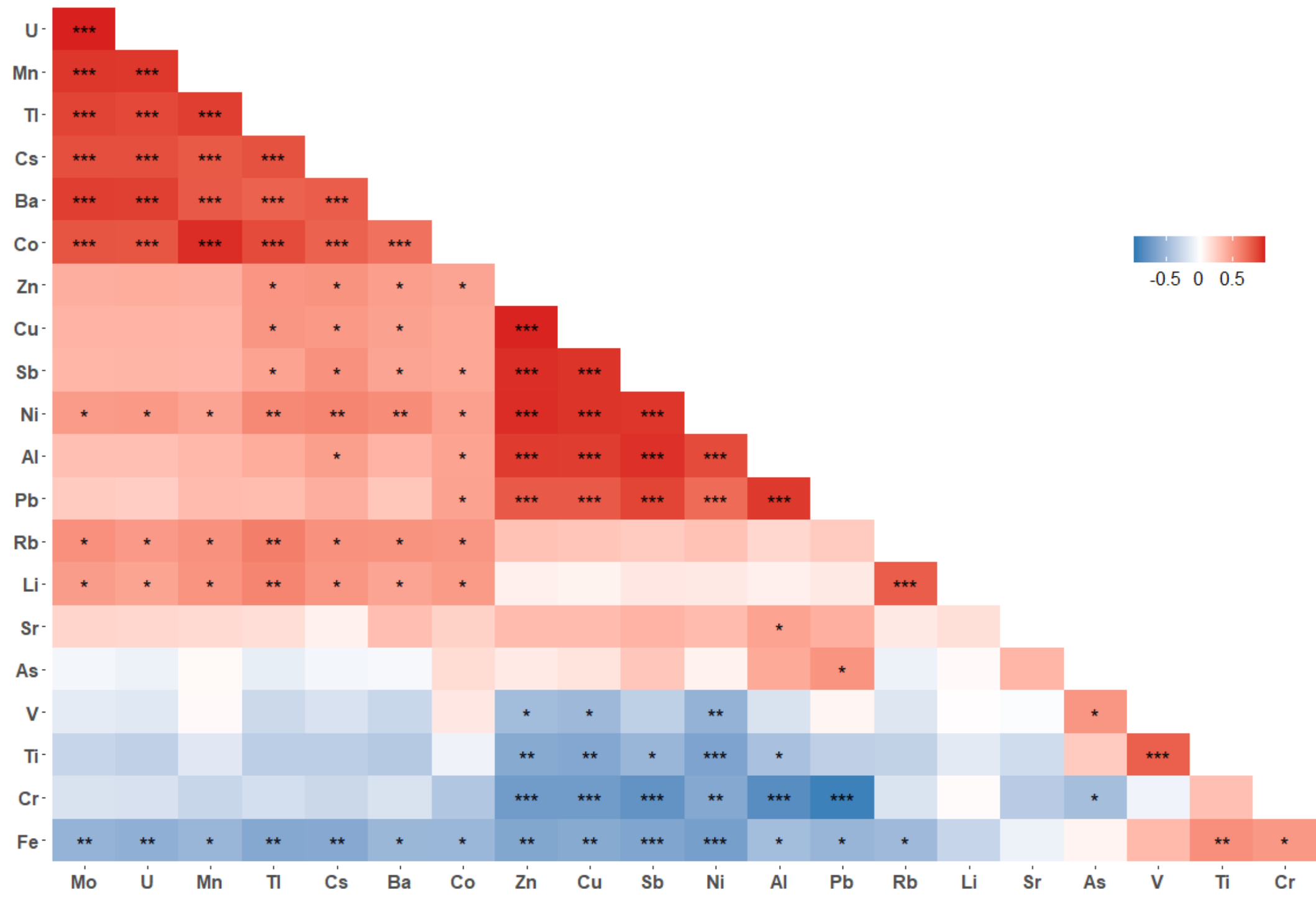

SI 1. Heatmap of correlation intensity between studied metals in the control condition. The color scale corresponds to Spearman's correlation coefficients. 1, 2 and 3 stars represent a pvalue $<0.05,<0.01$ and $<0.001$ respectively. 